\title{
PRODUCTION PAYMENTS
}

\author{
NEIL J. STEWART*
}

Because of the uncertainties and risks associated with natural resource production, special incentives for such production may be provided in taxation law. In Canada and the United States special Income Tax provisions allow for the use of the Production Payment-the sale in advance to a right of production-as such a tax incentive. The writer deals with two types of Production Payment, the Retained payment, and the Carved-Out payment. He sets out the essential features of both and outlines the position of the Tax Courts regarding each. The differences between such payments and normal royalties, and the position of Depletion are discussed. It is concluded that carefully planned production payments remain a useful device for natural resource industry financing.

Over the years, various inducements have been offered to investors to convince them that they should invest at least some of their money in the natural resource extractive industries, which commonly suffer from a shortage of investment capital. It is commonplace to say that the risks associated with investment in the extractive industries are significantly greater than those associated with many alternate forms of investment opportunity. Rather obviously then, some additional rewards for investment in the extractive industries must be offered to tantalize the owners of risk capital, or such industries would quickly become capital-starved.

One of the inducements to invest in the natural resource industries can be found in the special income tax allowances or treatment made available to taxpayers willing to make such investments. Much has been written in criticism of, or in justification for these allowances in the income tax structures of Canada and of the United States. It is not my purpose here to add further comment, pro or con, to these writings, but rather to discuss one type of investment in the natural resource industries, which would never be made but for these special allowances. This type of investment is commonly described as the purchase of a "production payment," that is, a payment which is returned to the investor from the production of some resource.

The sale of production payments has for many years been used by petroleum producers in the United States. The principle involved is the sale of production that would not ordinarily be recovered until some time in the future, for cash in the current year, thereby providing funds for, although not necessarily dedicating such funds to, some immediate or imminent petroleum operation. The investor is induced to make the investment provided for in the documents covering the arrangement because he is offered a chance to make a profit in return for assuming a part of the risk of the operation. The profit to the investor is measured by the difference between the rate of interest that he must pay on the money he borrows or uses to purchase the production payment, and the stated rate of so-called "interest" on the production payment. The so-called "interest" on the production payment is not real

- Of the Alberta Bar, Vice-President, Administration and Finance, Amoco Canada Petroleum Company Ltd., Calgary. 
interest in the conventional financing sense, because there is no debt or covenant to pay that is due to the investor from the vendor of the production payment, as will be explained presently. However, it does represent an additional fraction of the production from a property that will have to be paid over to the investor.

The risk assumed by the investor who purchases a production payment is not insignificant. He must look to his share of the minerals in the ground which are subject to a production payment as the sole means of recovering his investment and therefore becomes, during the period of payout of the production payment, a co-venturer with the operator of the property who sold him the payment. If the investor's assessment of the reserves in the property, or of the productivity of these reserves is unduly optimistic, he may not recover his money at all, or he may have to wait a much longer time than he had planned originally before his investment is recouped. He is subject to the vagaries of changing production allowables in the case of oil wells; productive capacities of wells which may change to his detriment; miscalculations of the amount of reserves remaining in the property in which he has invested; temporary field shutdowns by order of the appropriate conservation authority due to unsatisfactory gas-oil or water-oil ratios; delays while further wells are drilled to boost production from the property to expected levels; or other unpredictable occurrences. He must depend very heavily upon the competence of the operator of the lands in which he invests. He cannot look to the vendor of the production payment for guarantees of payment of his investment in cash or out of the production from other properties not subject to his production payment, or to any other guarantees whatever, because such guarantees cannot be given to him if he is to enjoy the benefits of the tax legislation applicable to production payments. He is committed to the output from the property, since payment must be solely dependent on production. Therefore he usually insists upon a ratio of unrecovered proven reserves, to production dedicated to satisfaction of the production payment, of at least $2: 1$ to protect himself.

Now let us assume that a prospective investor has satisfied himself through engineering information that the owners of Whiteacre have a potential bonanza for themselves, with a clear title to some 500,000 barrels of oil in one horizon; several billion cubic feet of very sour natural gas (i.e. gas having a high sulfur content) in another horizon; and perhaps a considerable amount of recoverable sweet natural gas and condensate in still another horizon. Let us also assume that the owners of Whiteacre have insufficient capital to properly develop and produce the bonanza which they own or that they have some other immediate need for capital. There are many possible courses of action open to them, but let us consider only those associated with production payments.

The owners of Whiteacre could dispose of the property by means of what is called an $A B C$ or "retained" production payment transaction, or they could sell a "carved-out" production payment to finance the costs of development and production and keep their title to Whiteacre. It is most important to characterize these two very distinct types of 
transactions rather precisely. They are constructed differently, serve different purposes and are attended by different tax consequences, although some people persist in discussing "retained production payments" and "carved-out production payments" as synonyms for the same basic transaction.

\section{The "Retained" Production Payment}

The "retained" production payment arrangement permits the acquisition of petroleum properties for a small cash consideration, but the properties are burdened by a large production payment which is retained by the vendor. The operator making the acquisition will naturally allocate some of the cash payment made by him to the equipment acquired, and will recover this cost through depreciation in the United States, or through capital cost allowance in Canada. That portion of the income stream which goes toward satisfying the production payment retained by the vendor is excluded from the income of the operator on the theory that a conduit pipe relationship has been established between the owner of the production payment and the purchaser of the production recovered from the well or wells in question. ${ }^{1}$ After the production payment has been discharged, the operator will own the full lessee's interest in a relatively valuable property, for which he paid only a small consideration.

For U.S. tax purposes, the operator capitalizes the acquisition costs he incurred, but claims allowable depletion against all income from the property which is received by him for his own account. The party which retained the production payment treats the sale of the operating interest to the operator as a capital disposition and claims depletion against the income payments received during the payout of the production payment.

For Canadian tax purposes, the results would be somewhat different. The operator would be entitled to claim a deduction for the sum spent by him in acquiring the operating rights from the original owner and would treat all monies that he received from the property as ordinary income subject to depletion under section 1201 of the Income Tax Regulations. ${ }^{2}$ The original owner of the properties would be required to take into income the cash sum received from the operator for the sale of the operating interests, but this is of course a relatively small amount, as was already mentioned. The monies received during payout of the production payment by the original owner should qualify as depletable income to him under section 1202 of the Regulations. ${ }^{3}$ The expression "should qualify" is used deliberately and advisedly, as will appear later.

Now let us briefly consider a refinement of the "retained" production payment arrangement, the well-known $A B C$ production payment. The ramifications of the $A B C$ deal have been discussed in a number of papers and books on the subject of taxation. A current and timely

1 Thomas v. Perkins 301 U.S. 655. But see Calgary and Edmonton Corporation Ltd. v. Minister of National Revenue [1955] C.T.C. 161 for an instance in which the conduit pipe relationship falled.

2 P.C. 1954-1917.

8 Id. 
review of its possibilities in Canada has been prepared by two Canadian writers, ${ }^{4}$ and it is not proposed to redo their work on the subject.

Dealing only with the basic relationships, $A$ is the owner of an oil or gas property which he wishes to dispose of absolutely. He conveys the property to $B$, an operator, for a small cash consideration, but retains from that transaction a large production payment worth a stated face amount plus interest at a specified rate on the unpaid balance. $A$ then sells the production payment to $C$, an investor, at its face value. $C$ finances the purchase of the production payment through a loan from a lender at a rate of interest which will be less than that stated for the production payment itself, pledges the production payment to the bank and assigns the income therefrom to the bank as security for the loan.

A number of variations of the classic form of $A B C$ deal have been developed as well. One consists of $C$ acquiring the entire interest of $A$ in the property and then selling the working or operating interest to $B$, subject to a large production payment retained by $C$. This variation is called, quite predictably, the $A C B$ deal.

The tax consequences in the United States of ABC deals are well known. $A$, who has disposed of his entire interest in the property, treats any profit therefrom as capital gain. $B$ has acquired the working interest for a small cash consideration and is entitled to allowable depletion upon all receipts from the property coming into his hands. $C$ is obliged to treat the difference between the lower bank interest rate and the higher production payment interest as income to him.

The tax consequences in Canada of participating in an $A B C$ deal are also well known. $A$ will be taxed on the full amount received by him for the disposition of his interest pursuant to section 83A(5b) of the Income Tax Act. ${ }^{5}$ As a consequence not many taxpayers want to take $A$ 's position in the transaction unless they have unused deductions against income tax in Canada. $B$ can claim a deduction under section $83 \mathrm{~A}$ (5a) for the amount paid by him to $A$ for the working interest and will also claim operator's depletion on all income received from the sale of production from the property. ${ }^{\circ} \mathrm{C}$ can claim a deduction under section $83 \mathrm{~A}$ (5a) for the amount paid to purchase the production payment, provided that there is secured to $C$ in the production payment arrangements the right to take his payment in kind, whether in oil, gas or other petroleum substances. C would claim non-operator's depletion, pursuant to section 1202 of the Regulations ${ }^{7}$ upon the payments received by him from the production payment and also on the interest received by him on the face amount of the production payment. $C$ would attempt to match the deduction created through his purchase of the production payment, with his receipts from the production payment in the following year or years, ${ }^{8}$ thereby avoiding tax on the payout of his investment.

Quite recently, a shadow passed across the otherwise clear sky above the tried and true procedures for obtaining approval of $A B C$

\footnotetext{
4 M. E. Jones, Q.C., and A. G. Burton, The ABC Transaction in Canada, (1965) Oll and Gas Taxes 2551. (Prentice-Hall Inc.)

R.S.C. 1952, c. 148.

- Income Tax Regulations, s. 1201

7 Id.

8 See Income Tax Act, s. 57 re: refund of overpayments of income tax.
} 
deals in the United States. Two decisions of the Tax Court of the United States, delivered in September of 1968, cast serious doubt upon the right of the operating party, $B$, to claim all of the expenses incurred in operating a particular property, even though it was burdened by a very substantial production payment in favor of an investor. In both the Brooks case ${ }^{9}$ and the Producer's Chemical case, ${ }^{10}$ the Tax Court was dealing with retained production payments. Both cases involved operating expenses that were incurred by the operator, $B$, in excess of his interest in production at that time. In both cases the Tax Court required $B$ to capitalize a portion of the operating expenses as being rightfully attributable to the costs of acquiring the production payments, on the basis that the assumption by $B$ of an obligation to pay all of these costs represents further consideration payable for the interests acquired, rather than deductible costs. It is understood that the Brooks case is to be appealed further.

The ratios of these two cases have been reflected in certain statements that have since been made about $A B C$ dealings by the Internal Revenue Service, which spread even further dismay among oil company taxpayers in the United States. While the situation still remains somewhat obscure, it is known that the Internal Revenue Service has suspended the issuance of rulings authorizing deductions by the working interest owner of the expenses of lifting substances subject to production payment deals in cases where losses are neither incurred nor anticipated. As a consequence, the economics of $B$ participating in an $A B C$ deal are certainly strained, but in many cases, the attractiveness of the deal is not altogether compromised. $B$ must now be even more circumspect with his calculations, and must use a certain amount of ingenuity to survive this new onslaught by the Internal Revenue Service from an hitherto unexpected quarter, in order to develop an arrangement which falls within his basic economic parameters. It can therefore be assumed that either Canadian or United States oil operators will continue to make use of $A B C$ production payment deals affecting properties in Canada when economic circumstances will justify them.

\section{The "Carved-Out" Production Payment}

The "carved-out" production payment is quite aptly named, in that it is an interest in production of relatively short duration that is carved out of and sold from an interest in production of longer duration. In the United States, where carved-out production payments first appeared, they were originally much used as a means of converting ordinary income into capital gain on the sale of the payment. But the decision of the Supreme Court of the United States in the Lake case, ${ }^{11}$ reversing the decisions of the lower courts in favor of capital gains treatment in the case of sales of carved-out production payments not dedicated to development of the property, held that such sales were not conversions of capital investment, but rather amounted to receipts in advance of ordinary income. However, the sale of carved-out production payments

\footnotetext{
9 Brooks v. Commissioner of Internal Revenue (1968) 50 T.C. No. 94.

10 Producer's Chemical Co. v. Commissioner of Internal Revenue (1968) 50 T.C. No. 95.

11 (1957) 355 U.S. 260.
} 
can still be used to generate ordinary income as an offset against operating losses, or as a means of improving the realization of allowable depletion in the United States.

A carved-out production payment involves the sale by the owner of the operating interest of a portion of his interest in production in kind and the right to take and recover such interest, and its retention by the purchaser until the latter has recovered from such production the stated face amount of the payment plus interest.

The tax treatment accorded carved-out production payments in the United States is easily understood. The Internal Revenue Service, since the Lake case, ${ }^{12}$ treats the consideration for the sale as a receipt of income in the year of sale. Since the receipts from the sale are deemed to be income to the recipient, then the seller is entitled to a depletion allowance upon the income received. The purchaser recovers the monies spent by him to acquire the carved-out payment through allowable depletion as production is recovered. When the full amount of the carved-out production payment plus interest has been recovered by the purchaser from the lands subject to the payment, his interest terminates automatically and the original owner of the production immediately thereafter claims the entirety of the operating interest for himself.

If the proceeds from the sale of a carved-out production payment or other production payment are specifically pledged by the seller to the development of the properties from which the payment is sold, the ratio of the Lake ${ }^{13}$ decision does not apply in the United States and the transaction is deemed to create no gain or loss, but rather a contribution by the purchaser to the capital costs needed to develop the property. The consideration paid for the payment in such circumstances must be applied in reduction of the development expenses of the seller, to the extent of the amount expended. If an excess over the amount expended results, then the excess is treated as income. ${ }^{14}$

Carved-out production payments can be sold to advantage in Canada as well. From a purely income tax standpoint, there would appear to be little advantage in the owner of an operating interest selling a portion of his interest in production that may be recovered in one or more future years in return for an immediate cash payment which is not depletable to the seller under Canadian law. However, there can be very compelling financial reasons for the creation of immediate cash in relatively large amounts, from an operating interest in petroleum or natural gas that would only generate such amounts through normal sales of production over periods of many months or years. Here is where the carvedout production payment transaction can be utilized to the benefit of the owner of the operating rights.

Let us trace the Canadian tax consequences which apparently attend the sale and purchase of a carved-out production payment. First, the seller converts depletable income from production in future years, into present income that is non-depletable and fully taxable in the year of sale. Next, the purchaser will be entitled to a deduction for the cost he

14 See Leland E. Fiske, Federal Taxation of Oil and Gas Transactions, (1958) 175 and $f f$. 
incurs in acquiring the production payment pursuant to subsection (5a) of section 83A of the Income Tax Act, provided that he acquires from the seller a . . . "right . . . to take in Canada petroleum, natural gas or other related hydrocarbons . . .". It is understood that a "right to take" of the kind referred to in subsection (5a) of section 83A must include the right to recover one's own share of petroleum in kind, and not just the proceeds from the sale thereof. Furthermore, the conveyance to the purchaser must vest in him a right to his share of the petroleum substances in the reservoir, and not just in tanks or at the wellhead after recovery from the well, if the purchaser is to be able to claim the deductions and depletion allowances applicable thereto. To secure such rights, many conveyances grant to the purchaser a right to the petroleum substances in place in the reservoir and also a right to use the well or wells drilled thereto for the purpose of recovering his share of production from the reservoir, without at the same time transferring to the purchaser any operating rights, or rights of ownership in the well or wells or in the capital equipment. Carved-out production payment deals ordinarily sedulously avoid any transfer of interest in operations or in the ownership of capital equipment, since such transfers are not really necessary to the efficacy of the deal, and also because such transfers are fraught with such distasteful complications as infringements of prior rights of purchase in favor of partners of the operating party; or serious dislocations of the investment account covering tangible or depreciable assets. Furthermore, there may be a complete incapacity to assign the rights of operating a particular tract of land to be made subject to the production payment. Therefore only the right of use of the well or wells is conveyed to the purchaser.

But now the tax waters across which the purchaser has been trying to navigate become considerably more turbulent and murky. Let us assume that a taxpayer has purchased a carved-out production payment of $\$ 100,000$ payable out of $85 \%$ of all of the petroleum substances of any kind, including sulfur, which may be recovered from Whiteacre commencing on January 1, 1969 and estimated to be paid out in one year, at an interest rate of $6 \%$ per annum. Let us also assume that the conveyance of his interest in Whiteacre was such as to comply with the requirements elaborated upon above, and that therefore the purchaser should be entitled to a deduction of $\$ 100,000$ in 1968 , when he bought the production payment, pursuant to the provisions of section $83 \mathrm{~A}$ of the Income Tax Act. The type of taxpayer involved with the purchase of the carved-out payment will determine which subsection, if any, of section $83 \mathrm{~A}$ should be used by him to support his claim for a deduction.

Clearly, the best group of taxpayers in which the purchaser can find himself is that embraced by subsection (3b) of section $83 \mathrm{~A}$, since a corporation qualifying for a deduction under this subsection can claim it against any of its Part I income. The reason for the choice of corporations named in subsection $(3 \mathrm{~b})$ is, the writer suspects, like the identity of the unknown soldiers to whom we pay our respects on Armistice Day, "Known but to God." Such heterogeneous entities as companies whose principal business is production, refining or marketing of petroleum; mining or exploring for minerals; processing mineral 
ores in order to recover metals therefrom; processing metals; fabricating metals; or operating a pipeline for the transmission of oil or gas, are all permitted to qualify.

If the taxpayer proposing to acquire a carved-out production payment is a corporation other than those described in subsection $(3 \mathrm{~b})$ of section 83A, or if such taxpayer is an individual, certain gymnastics must be performed under section $83 \mathrm{~A}$ if utter disaster is to be averted. As already indicated above, it appears certain that a deduction is allowed such taxpayers for the costs of acquiring the carved-out payment, but this deduction, if it is to have any benefit to the taxpayer, must be applied against some part of the taxpayer's income, or it becomes academic and totally worthless. The corporate taxpayer which is not of the kind described in subsection $(3 \mathrm{~b})$, or the individual taxpayer must claim the deduction for the costs of acquiring such a right against a critical and discrete type of income, as set out in subsections (4b) or (4c), whichever is appropriate, if the deduction is to be availed of.

The concept of a deduction being granted to a taxpayer under one provision of the Income Tax Act which cannot be actually utilized because of the application of another provision of the Act may seem a non sequitur at first blush, but there really are a number of instances in which such a result can obtain. For example, consider the deduction for depletion in respect of production from an oil or gas well apparently allowed pursuant to section 11(1) (b) of the Income Tax Act during those years when a taxpayer is not earning sufficient income to offset all of his current and prior expenses incurred in exploring for, drilling for and producing oil and gas in Canada. Another example would be the claim for deductions in Canada for foreign taxes paid by a taxpayer during years when he has insufficient income from Canadian sources to utilize these deductions. In both of these examples and in a number of others that could be cited, the unhappy taxpayer may find himself asking the question, "I have a button; have you got a coat for me?"

Now, to return to the subsection (4b) corporation or to the individual that acquires a carved-out production payment, the receipts from the payout of any production payment are taxed pursuant to section $6(1)(j)$ of the Income Tax Act, as . . . "amounts received by the taxpayer in the year that were dependent upon use of or production from property. ..."The taxpayer can stand this tax if a deduction for the costs of acquiring his income-producing right can be claimed and utilized, but he most certainly will not expose himself to the rigors of section $6(1)(j)$ if there is a chance of this deduction eluding his grasp.

Subsection (5a) of section $83 \mathrm{~A}$ is the fountainhead of the deduction under the Income Tax Act for the costs of acquiring a right to take petroleum in Canada, providing as it does that an amount paid for such a right . . . "shall, for the purposes of subsections (3b), (3d), (4b) and (4c), be deemed to be a drilling or exploration expense. . . ." Subsections (3d) and (4a) are really not appropriate to an acquisition of a carved-out production payment for obvious reasons, and subsection (3b) applies only to corporations of the kind therein described, as has been discussed earlier. Therefore the taxpayer must satisfy the Depart- 
ment of National Revenue that his receipts from the payout of a carvedout production payment are income within the meaning of subsections (4b) or (4c) if he is to be able to utilize the deductions he claims pursuant to subsection (5a) for the costs of acquiring the production payment.

Dealing first with the subsection (4b) corporation, clearly such a taxpayer cannot argue that its income from a carved-out production payment which it has acquired arises from "operating an oil or gas well in Canada" within the language of paragraph (b) (i) of subsection (4b), because no rights to operate an oil or gas well are conveyed with the production payment. On the other hand, if the purchaser of the production payment is an inidvidual, he will find in paragraph (b) (i) of subsection (4c) certain differences in language which would certainly appear to place him in a position which is superior to that in which the subsection (4b) corporation finds itself. The individual can argue that his receipts from the payout of a carved-out production payment are income to him ". . . from a business that consisted of the operation of an oil or gas well in Canada in which the individual had an interest. . . ." It is worthy of note that the individual is not required to actually operate the oil or gas well (as is the subsection (4b) corporation), but rather only to have an interest in a business consisting of such an operation. This the individual can logically assert, when he has a right to take in kind his share of petroleum produced by an oil or gas well, even though the well is operated in fact by his co-venturers who sold him the production payment.

Since taxpayers, like fiddlers, should have more than one string to their bows, the subsection (4b) corporation and the individual are bound to assert that receipts from the payout of a carved-out production payment are ". . . income for the taxation year from royalties in respect of an oil or gas well in Canada. ..." within the language of paragraph (b) (ii) in each of subsection (4b) or subsection (4c), whichever is appropriate. But here we, like the Three Billy Goats Gruff in the nursery rhyme, meet the old, old Toll who menaces the bridge to the green fields beyond; for it is understood that several taxpayers have recently discussed carved-out production payments with the Taxation Division in Ottawa and the position taken by the Department is that the income from such payments is not a royalty.

A royalty is defined in the Oxford International Dictionary as, inter alia, ". . . a payment made to the landowner by the lessee of a mine in return for the privilege of working it." Perhaps the position of the Department respecting royalties in this context is inspired by the fact that the purchaser of a carved-out production payment ordinarily does not strike any bargain with the landowner possessing the petroleum substances in place, but rather with the owner of the operating rights. In any event, it appears that a taxpayer will have difficulty with the Department if he claims that his production payment receipts are really royalties for purposes of subsection (4b) or subsection (4c). Contrast this position of the Department, if you will, with its position respecting payments made to a foreign destination from the payout of a production payment, in connection with which the Department would definitely 
assess a tax of $15 \%$ pursuant to section $106(1)(d)$, on the grounds that the payment is a "rent, royalty or similar payment" to a non-resident.

Canadian courts have reached decisions in a number of cases which support the contention that payments of the sort received by the owner of a carved-out production payment are royalties. In Ross v. Minister of National Revenue, ${ }^{15}$ the Exchequer Court of Canada dealt with a contention by the taxpayer that receipts from the sale of production were really part of the consideration for a sale and not income in the nature of rents, royalties, annuities or other like periodical receipts giving rise to income. In this case, the executrix of the will of Annie McDougall transferred all hydrocarbons except coal in certain lands in Alberta and the right to work the same to Royalite Company Ltd. in consideration of a sum in cash and the execution of an incumbrance to secure a further sum of $\$ 60,000$, payable out of $10 \%$ of the oil produced from the land, with the option to the company to pay her the cash market value of such production. The company paid certain sums in 1944 and 1945 which the appellant did not include in the estate returns for those years. The respondent considered these sums "income" within the meaning of section 3(1) (f) of the Income War Tax Act ${ }^{16}$ and allowed a deduction of $25 \%$ thereof for exhaustion and assessed tax on the balance.

Section $3(1)(f)$ reads as follows:

For the purposes of this Act, "income" ... shall include ...

(f) rents, royalties, annuities or other like periodical receipts which depend upon the production or use of any real or personal property, notwithstanding

that the same are payable on account of the use or sale of such property.

The appellant argued that her receipts were neither royalties nor like royalties because they did not depend upon the production of any real or personal property. It was further argued that, although "royalty" was not defined in the Act, "royalty implies a transaction which has some reddendum, some retention such as exists between the relationship of lessor and lessee where there is a fixed royalty obtained, not for a partial time, but for the lifetime of the property."

Cameron J. held that there was no authority for the proposition that a royalty must exist for the life of the property from which it is payable. He also stated he had been unable to find any decision which says that a royalty can only be created where there is something reserved out of a demise or grant and payable to an owner. From the language of the section itself, the Court felt it was not obliged to find that the payments were in fact royalties, in order to find against the appellant, because it was sufficient if the Court could find that the payments were "like" rents, royalties, or annuities, provided the other requirements of the subsection were fulfilled. The Court found that the payments in question were like royalties, if not royalties themselves, and therefore were within section $3(1)(f)$. The Court also overruled the contention of the appellant that even if the payments were like royalties, the fact that they ceased upon her receipt of $\$ 60,000$ therefrom established that her receipts were part of the purchase price and therefore were capital in her hands. Cameron J. held that mere cessation of the payments after a certain sum was reached could not change their character.

$15[1950]$ Ex. C.R. 411.

16 R.S.C. 1927, c. 97, as amended. 
In No. 54 v. Minister of National Revenue, ${ }^{17}$ the appellant and his partner, who were brick manufacturers, rented some land on which was located clay, machinery and other equipment. The appellant sold the clay to two individuals who agreed to pay on a basis of $2 \frac{1}{2}$ million bricks per annum, a price calculated at $\$ 2.00$ per thousand bricks for the first $11 / 4$ million bricks manufactured and $\$ 1.00$ per thousand for the remaining 11/4 million bricks. The profits of the appellant for 1948 and 1949 were considered by the Minister to be income under section 3 (1) (f) of the Income War Tax Act, ${ }^{18}$ but the appellant argued that the monies in question were payments for the manufacturing plant after payment made by him to the brick company. Fordham J., applying the Ross v. M.N.R. decision, ${ }^{19}$ held that the

... payments received by the appellant in 1948 were "periodical receipts which depend upon the production or use of any real or personal property," and were embraced by paragraph (f), accordingly." 20

In 1952, the Supreme Court of Canada decided Minister of National Revenue v. Wain-Town Gas and Oil Company Ltd.,"2 a decision containing one judgment which characterized a series of payments based upon the production of natural gas as royalties, and not one or the other of "royalties or other like periodical payments," upon which some of the other judges equivocated in the decisions cited above.22 For this reason, the judgments should be examined closely. The facts before the Court indicated that the respondent company had assigned to Franco Public Service Company its franchise to supply natural gas to the Town of Vermilion in Alberta, for a period of ten years from 1938, with the option of renewal indefinitely for further ten-year periods. The consideration for the assignment was a covenant by the Service Company to pay to the respondent company:

By way of royalty, from the proceeds of all sales of natural gas under the said franchise, the following percentages of the actual gross sales of gas reckoned at consumers' prices, less consumers' discounts:

(a) During the first three years, $61 / 4 \%$;

(b) During the next seven years, $81 \% 3 \%$;

(c) Thereafter during the currency of this agreement, and of the said franchise, $121 / 2 \%$.

The Minister assessed these monthly payments as taxable income for the years 1944 and 1945 under section 3 (1) (f) of the Income War Tax Act. ${ }^{23}$ The Exchequer Court set these assessments aside, and this appeal was then taken to the Supreme Court of Canada.

In a judgment concurred in by the Chief Justice, Kerwin, and Taschereau J.J., the Court restored the assessment. After reviewing a number of English and Canadian decisions referring to the use of the word "royalties," Kerwin J. held as follows:

In a business sense in Canada it ("royalties") covers the payments which were

to be, and were, paid monthly by way of percentages of the actual gross sales ... "of natural gas under the said franchise."

However, not wanting to commit himself entirely to the proposition that

17 (1952) 6 Tax A.B.C. 345.

18 R.S.C. 1927, c. 97, as amended.

18 [1950] Ex. C.R. 411

20 See also Mr. R. v. Minister of National Revenue (1950) 2 Tax A.B.C. 364.

21 [1952] S.C.R. 377 .

22 Ross v. Minister of National Revenue [1950] Ex. C.R. 411: No. 54 v. Minister of National Revenue (1952) 6 Tax A.B.C. 345; Mr. R. v. Minister of National Revenue (1950) 2 Tax A.B.C. 364 .

23 R.S.C. 1927, c. 97, as amended. 
payments of the sort received by Wain-Town were of necessity "royalties," he went on to say that even if such payments were not received as royalties, "they fell within the expression 'other like periodical receipts" "and as such were caught by section $3(1)(f)$.

Rand J., in a separate judgment, was more specific and more helpful to us in settling just what is a royalty. He said:

The word "royalties" is best known, perhaps as a term to express an interest in the nature generally of future payments upon a grant or lease of mines, such as gold, coal, petroleum or gas rights; and it makes no difference in substance or as to the nature of the payments, whether they arise through "a reservation," strictly so-called, or a covenant.24

He went on to hold that the question is whether such payments "depend upon the production or use" of property, and that the word 'use' is appropriate to the exercise of a franchise such as that which was the subject matter before the Court. Since the property in question was the franchise, the royalty was payable on account of the sale of it, and the payment was to depend upon its exercise, the payments in question were within the meaning of the section. Rand J. did not fall back on the alternative language of the section dealing with "like periodical receipts," but held that the payments were "royalties" pure and simple.

Locke J. wrote the only dissenting judgment, and held that the payments in question were instalments on account of the purchase price and were therefore of a capital nature, because the agreement involved an outright sale of the franchise to Franco Public Service Company without any reservation. With respect, it is most difficult to square the conclusion of Locke $J$. that the payments in question were not within the meaning of the section because they related to the purchase price for the outright sale of personal property, with the express language of section $3(1)(f)^{25}$ which includes in income rents, royalties or annuities ". . . notwithstanding that the same are payable on account of the use or sale of any such property. ... " Such wording makes no distinction between outright sales and sales involving the reservation of rents, royalties or annuities. Locke $\mathrm{J}$. hung his decision on a distinction that is expressly overruled by the section, and it is therefore not surprising that his was the lone dissenting decision.

The parallel between the type of, or the nature of the payments made in the Wain-Town case and those made in paying out a carved-out production payment, seems to the writer inescapable. In both cases, the payments vary with and are calculated as a percentage of the production from the lands made subject to the payments. The landowner's interest in the lands or in the production therefrom is neither affected by nor involved in either situation, since the dealings in both situations are between parties who are later in the chain of title than the landowner. The fact that the royalties considered by the Supreme Court of Canada in the Wain-Town case go on indefinitely whereas a carvedout production payment ceases when a certain predetermined sum has been received, cannot be considered a valid distinction between the two as to their character or nature, as established by Cameron $\mathrm{J}$. in the Ross v. Minister of National Revenue case. 
Another and more recent case, with a close bearing upon the meaning of the term "royalties," is the decision of Fordham, Assistant Chairman, in Harrington \& Bibler Ltd. v. Minister of National Revenue. ${ }^{20}$ The question before the Income Tax Appeal Board in this case was whether or not certain payments received by the appellants, who were professional geologists, from the lessees of certain leases, were really royalties subject to depletion in the hands of the recipients, or were rather payments for services rendered and therefore non-depletable. The payments were described in the documents between the appellants and the lessees as overriding royalties, varying from $1 \%$ to $3 \%$ of the production of oil and gas recovered from various described lands. The agreements did not assign to the appellants a portion of existing royalties between the lessees and the landowners; instead new royalties were created between the lessees and the appellants. The Assistant Chairman referred to a number of the authorities cited above ${ }^{27}$ and quoted directly from the language of Kerwin J. in the Wain-Town case in support of his conclusion that a royalty "is a payment, measured by production, for the temporary or complete cession of some right or interest in property." He therefore concluded that the appellants were entitled to deplete their receipts from the properties in question and allowed their appeal. Strangely, although the Assistant Chairman apparently relied heavily upon the Wain-Town decision in framing his ruling, he did not specifically cite the judgment of Rand $J$. in that case which had more direct application to the point before him than the judgment of Kerwin J.

It has been suggested that because the sale of a production payment usually transfers to the purchaser a very large fraction of the production from the property during the life of the production payment (from $80 \%$ to $90 \%$ of the production runs in many instances), the magnitude of the interest so transferred is such as to make it too great to be considered a royalty. There is no jurisprudence that the writer has been able to find anywhere that gives succor to this belief. Furthermore, if a cessation of payments of royalties after a period of time cannot change their character, which is a specific finding of Cameron J. in Ross v. Minister of National Revenue, ${ }^{28}$ the writer fails to see any logic in the argument that a particular payment measured by production may be a royalty so long as it remains in the range of $1 \%$ to $20 \%$, but that it changes its character to some other unspecified type of payment if it involves the payment of $80 \%$ to $90 \%$ of the production to the recipient. It is difficult in the extreme to conceive of quantitative rather than qualitative considerations being used to determine the character of income subject to the Income Tax Act.

It would be the writer's submission that, in the light of the Canadian jurisprudence on the matter of royalties, the Minister of National Revenue would indeed have very heavy weather from the courts were he to assert in any litigation that the receipts from a carved-out production payment are not royalties within the Income Tax Act and the Regulations thereunder.

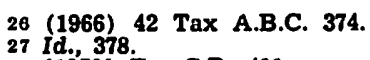




\section{Depletion}

As mentioned earlier in this article, a taxpayer who purchases a production payment, whether of the retained or of the carved-out variety, is entitled to depletion on the amounts received by him therefrom, because he must look to the production of oil or gas from a particular property, and only to that production as a means of recovering his investment.

Because the owner of a production payment does not acquire the right to operate oil or gas wells, he is not ordinarily thought of as a "person who operates the resource," within the meaning of section $1201(1)(b)$ of the Regulations. However, the owner of a production payment may argue that he does share in the proceeds of production from a "resource" (i.e. an oil or gas well, as provided in section 1201 (1) (a) of the Regulations) in that he shares in the profits remaining after deduction of the costs of operating the resource, and should therefore be deemed an "operator" for depletion purposes. But against this contention is the fact that the production payment, whether retained or carved-out, is made to the owner thereof by the real operator of the property out of $80 \%$ or some other percentage of the production from the property affected, quite apart from and regardless of operating costs. The real operator may retain for himself a sufficient interest in production to defray the operating costs which he anticipates will be incurred while the production payment is in effect. But the operator's estimate of operating exepnses may not be accurate, and to the extent of any such inaccuracies, the operator will enjoy a profit or endure a loss while the production payment obligations continue, unless the deal in which he has involved himself provides for a variable dedication of production to satisfaction of the production payment which will fluctuate with variations in operating expenses.

It is doubtful also that the owner of a production payment would want the $331 / 3 \%$ depletion allowance available to the operator of a resource, pursuant to section 1201(2) of the Regulations, because this allowance is a net sum, calculated against the profits from production of oil or gas from the property in question after prior deduction of all losses attributable to the production of oil or gas operated by such taxpayer, and any deductions for capital cost allowance, exploration and production expenses, plus a number of other deductions referred to in subsection 4 (b) of section 1201 . In a nutshell, the owner of a production payment would run the risk of realizing no depletion at all if his claim therefor had to rest on the "operator's" allowance created under section 1201 (2) of the Regulations, even if he qualified for it.

It is the deduction provided for in section 1202 of the Regulations for persons other than operators, that is more appropriate to the tax circumstances of the owner of a production payment. To qualify for this deduction, the taxpayer who is other than an operator may base his claim upon the fact that he owns an interest in a "resource and in the proceeds from the sale of the products therefrom," which means that the person must have an interest in "an oil or gas well" as provided in paragraph (i) of section 1201 (1) (a) of the Regulations. To give the words "an oil or gas well" their narrow, technical meaning in this context would 
require the taxpayer to share in the ownership of the hole that is drilled to the reservoir containing oil, or gas, or both. To call such an interest, with nothing more, a "resource" seems an empty play upon words, because the hole itself is virtually valueless. The oil or gas well acquires value only when its ownership is linked to some rights of ownership of the reservoir penetrated by the well and to its contents, if there is to be anything of value taken from the well and sold.

Therefore, it would seem that the words "an oil or gas well" are neither accurate nor comprehensive in defining the type of interest which must be held by the taxpayer if he is to assert that he has an interest in a "resource" for purposes of this paragraph (i). It is principally for this reason that the writer urged upon the reader earlier in this article that the owner of a production payment should secure for himself in the agreement covering his interest, a right of user of the oil or gas well and an interest in the petroleum substances in kind in the reservoir.

Alternatively, the taxpayer who is other than an operator may found his claim for depletion of his receipts from the payout of a production payment upon the fact that he owns a rental or royalty, computed in accordance with the amount or value of production from an oil or gas well. Pursuit of this alternative again raises the question already discussed at some length in this article, as to whether or not the payout of a production payment is in the nature of a royalty. Although the decisions of the courts very strongly suggest that such payments are royalties, it is apparent that the point will probably not be litigated in connection with a claim by a taxpayer for depletion pursuant to section 1202 of the Regulations, since his right to depletion allowance seems secure in any event, so long as he has an interest in a resource and in the proceeds from the sale of production therefrom.

The depletion allowance granted under section 1202 of the Regulations is $25 \%$ of the amounts received from the interest in the proceeds of production or from the rental or royalty, without deductions of any kind. As such, this allowance for depletion is a gross amount that can be predicted with considerable accuracy, and is of critical importance in inducing taxpayers to risk their money on investments in oil or gas development or production operations.

\section{Conclusion}

In conclusion, the writer should like to say that the use of production payment arrangements as means of providing financing for the development and operation of oil and gas reserves has been and continues to be worth while to operators and investors alike. The tax laws applicable to production payment deals must be subjected to a close scrutiny before the deals are consummated, needless to say, because minor changes in such laws can have dramatic consequences upon the interests of the participants therein. We in Canada have not heretofore made the use of production payment financing that we could have, and in the writer's opinion, it is incumbent upon us in the future to make better use of the techniques and arrangements that are available to us, so long as the income tax burden associated therewith is one that the taxpayer can bear. 